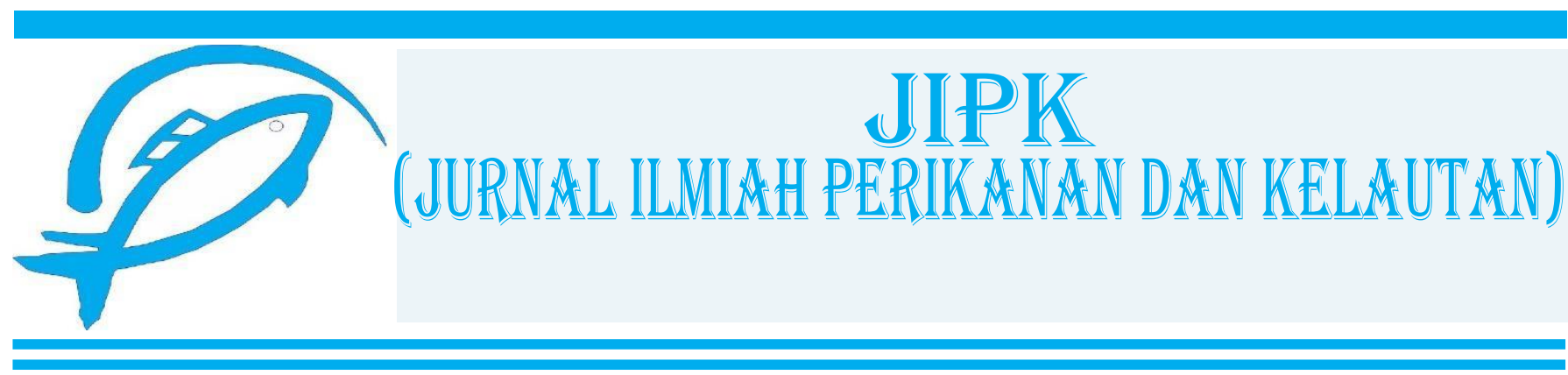

Research Article

\title{
Growth and Population Parameters of Panulirus penicillatus and Panulirus homarus in Labangka Tidal Waters, Indonesia
}

\author{
Evron Asrial ${ }^{1 *}$ (D), Erwin Rosadi ${ }^{2}$, Hamid ${ }^{3}$, Muhammad Ichsan ${ }^{4}$, Ruly Isfatul Khasanah ${ }^{5}$, Naning Dwi \\ Sulystyaningsih $^{3}$, Agustin Dwi Sumiwi ${ }^{6}$, and Najiah Khalisah ${ }^{7}$ \\ ${ }^{1}$ Department of Fisheries Resources Utilization, Faculty of Fishery, University 45 Mataram, 83239, Nusa Tenggara Barat. \\ Indonesia. \\ ${ }^{2}$ Department of Fisheries Resources Utilization, Faculty of Fishery and Marine, Lambung Mangkurat University, Banjarbaru, \\ Kalimantan Selatan. Indonesia \\ ${ }^{3}$ Department of Aquaculture, Faculty of Fishery, University 45 Mataram, 83239, Nusa Tenggara Barat. Indonesia \\ ${ }^{4}$ Wildlife Conservation Society. Bogor 16128, Jawa Barat. Indonesia \\ ${ }^{5}$ Department Marine Science, Faculty of Science and Technology, State Islamic University of Sunan Ampel, Surabaya, Jawa \\ Timur. Indonesia \\ ${ }^{6}$ School of Engineering Ranaco Education \& Training Institute, PT 4568, Chukai, 24000, Kemaman, Terengganu, Malaysia. \\ ${ }^{7}$ Universiti Malaysia Terengganu, (UTM) 21030 Kuala Terengganu, Terengganu, Malaysia
}

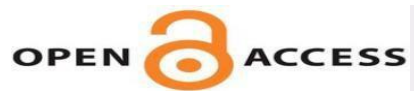

\section{ARTICLE INFO}

Received: August 08, 2020

Accepted: September 22, 2020

Published: September 27, 2020

*) Corresponding author:

E-mail: evronasrial81@gmail.com

Keywords:

Cemplung

Excessive Fishing

Key Attributes

Tidal

This is an open access article under the CC BY-NC-ND license (http://creativecommons.org/licenses/by-nc-nd/4.0/)

\section{Abstract}

The Labangka tidal waters, located south of Sumbawa Regency are the habitat and potential fishing ground for lobsters. The dominant species caught by the Labangka fishermen are the Panulirus penicillatus and P. homarus. Fishing pressure is one of the greatest factor influencing the biological and stock condition of lobsters in Labangka. The aim of this study is to determine the key attributes in growth and population parameters. Some attributes whose values are relatively stable compared to that of 2015, consist of conditional factors such as (old age), growth pattern (hypoallometrsic), growth coefficient (slow growth), exploitation rate (overexploited), and fishing rate (excessive fishing). While, attributes that have improved are carapace length at first capture (CLc) longer than $50 \%$ carapace length of infinity $\left(0.5 \mathrm{CL}_{\infty}\right)$ and $\mathrm{CL}$ rate $\left(\mathrm{CLc} / 0.5 \mathrm{CL}_{\infty}\right)$ reaching more than 1.00 (CLR > 1.00). In implementing sustainable management of spiny lobster for fishery resources, improvisation is needed in place of catching technologies. One of the recommendation is to add more fishing vessel $\left(\mathrm{L}_{\text {boat }}>17.0 \mathrm{~m}\right)$ equipped with engines that are able to reach potential fishing ground in the west waters of Cemplung beach, Labangka.

Cite this as: Asrial, E., Rosadi, E., Hamid, Ichsan, M., Khasanah, R. I., Sulystyaningsih, N. D., Sumiwi, A. D., \& Khalisah, N. (2020). Growth and Population Parameters of Panulirus penicillatus and Panulirus homarus in Labangka Tidal Waters, Indonesia. Jurnal Ilmiah Perikanan dan Kelautan, 12(2):214-223. http://doi.org/10.20473/jipk.v12i2.21486 


\section{Introduction}

A new chapter in the management of spiny lobster resources (Panulirus spp) in Indonesia has begun since the Regulation of the Ministry of Marine Affairs, and Fisheries (MMAF) Number: 01/Permen-KP/2015 and Number: 56/Permen-KP/2016 was issued. Both Ministries are related to the management of lobster, crab, and blue swimmer crab resources. Furthermore, this two regulations govern the minimum size of lobster that can be caught, and traded, namely carapace length (CL) of more than $8.0 \mathrm{~cm} /$ fish or body weight (BW) of more than $200.0 \mathrm{~g} /$ individualal. The aim of this study is to maintain the existence, and availability of lobster fishery resources for it to remain sustainable in Indonesian waters. The regulation also prohibits the capture of spawning lobsters in order to provide them with the opportunity to hatch their eggs, and increase their population, for them not become extinct.

The Ministry Regulation has an impact on price escalation, extraction, production, and degradation of lobsters, and their seeds. All of these impacts affect Indonesia's foreign exchange income, lobster farming activities, and Indonesia's balance of trade. Two out of the seven types of Panulirus that live and breed in Indonesian waters as a fishery commodity, lives in tidal waters near the coast. This two types are pronghorn spiny lobster ( $P$. penicillatus), and scalloped spiny lobster ( $P$. homarus). Their habitat spreads across the Indian Ocean, which stretches from Sumatra, and Java to the Lesser Sunda region (Junaidi et al., 2010; Kembaren et al., 2015; Larasati et al., 2018; Pratiwi, 2018; Munandar, 2019; Salim et al., 2019). One of the potential farming location for P. penicillatus, and

$P$. homarus in West Nusa Tenggara Province is the Labangka Beach, South Sumbawa (Munandar et al., 2019; Salim et al., 2019). Indonesian fishermen, and their community calls $P$. penicillatus by the term lobster batu and P.homarus by the term lobster pasir.

$P$. penicillatus in Sumbawa Regency is not considered a hot commodity in fishery subsector (Salim et al., 2019). Furthermore, the management of $P$. penicillatus resources in Labangka has had issues with it, because its utilization is still low (44.13\%, Lightly Exploited) (Munandar et al., 2019). They also explained that the age of a lobster can be considered old when it has a low condition factor.

The value of its growth pattern is smaller than 3.0 (hypo-allometric) which indicates a thin body size (Munandar et al., 2019; Salim et al., 2019). According to Salim et al. (2019), it is believed that its peakspawning period only occurs once per year during the transition from summer to rainy season (May-August).

In Tabanan waters (Bali), growth patterns of male, female, and combined (not separated) $P$. homarus is greater than 3.0 or allometrically negative (Kembaren et al., 2015). Furthermore, the ratio of female lobsters having eggs is high during June to September, and reaches is peak in October, and also at its lowest from March to May. Whereas for $P$. homarus in Lombok's Ekas Bay, its peak spawning period starts in June, and end in November (Junaidi et al., 2010).

The purpose of this study was to determine the impact of lobster fishery resource management after five years since the MMAF Ministerial regulations in 2015, and 2016 was issued. This study aims to determine $P$. penicillatus, and $P$. homarus growth parameters, and population status in Labangka (Sumbawa Regency) as a fishery resource of high economic value.

\section{Materials and Methods}

\subsection{Research Location and period}

This study was conducted at Labangka beach (Labangka District) which is the southern coastal area of Sumbawa Island (Figure 1). Sampling and compilation of lobster data were conducted in an area where lobster collectors congregate, which is located at Cemplung beach, Jaya Makmur Village (Labangka District). However, all lobster samples came from Labangka waters, and during the 5 months (AprilAugust) study, the waters temperature reached $30^{\circ} \mathrm{C}$ during daytime.

\subsection{Materials and equipments}

The main components of this study was $P$. penicillatus, and $P$. homarus obtained from collectors at Cemplung beach. All the lobster samples came from lobsters that were caught by Labangka fishermen in Labangka coastal waters. The fishermen used gillnets as a lobster fishing gear that is operated in coastal waters dominated by rocks, and slightly sandy at the bottom. This equipment consists of a digital scale, caliper,ruler, stationery, and a camera.

\subsection{Data collection}

During the period of research, the authors visited the research location 8 times to collect data. Furthermore, the purpose of visiting the research location was to discover natural phenomena, and lobster fishing activities. The types of data collected were primary data (cross-section data), and secondary data (second-hand data). 


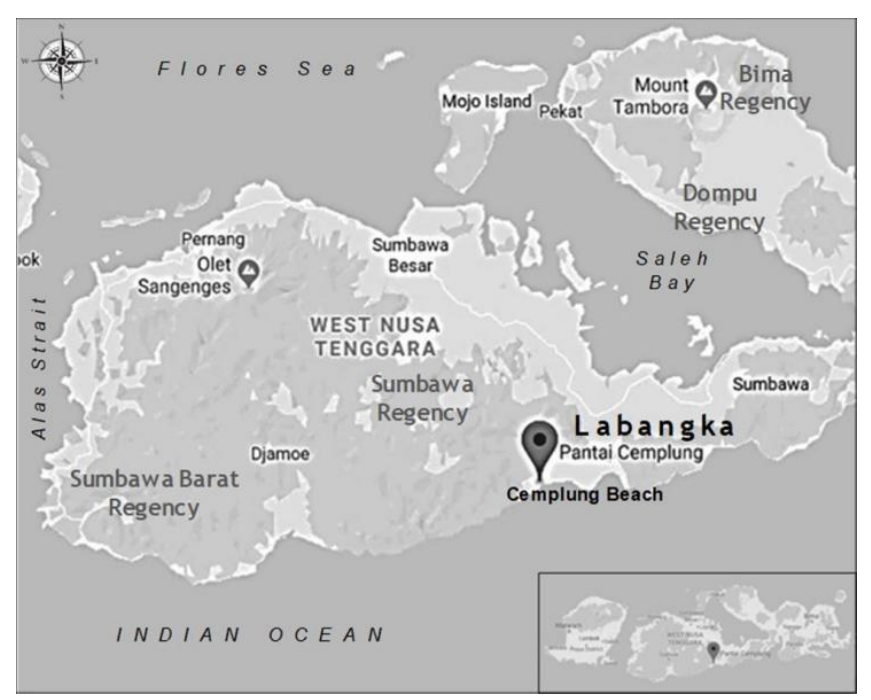

Figure 1. Map of research location

The process of data collection used in this research was the survey-descriptive-dependent method. The authors, when collecting samples and data, were very dependent on other parties who are involved in lobster fisheries. Data on lobster biological dimensions were obtained by measuring, and weighing lobster samples procured from collectors who had purchased them from Labangka fishermen. Meanwhile, data on lobster technology utilization were obtained from interviews with the fishermen, and also from identifying lobster fishing equipment.

Data on lobster carapace length measurements were gotten from the middle part of the supra-orbital to the center of the posterior carapace (Sparre and Venema, 1998) using a digital caliper. Lobster weight data were obtained from measuring lobster body weight using a digital scale.

Data were collected from April to August 2019, while lobster measurement data were collected from May to July 2019. Data processing, and analysis were carried out throughout August 2019, and ended with writing of the research report.

\subsection{Data processing and analysis}

\subsubsection{Growth parameters}

Condition factor (CF) is part of growth parameters to estimate if the condition of lobster fish is feasible to be caught, eligible for sale, and for processing so that it is suitable for human consumption. CF value is a comparison of $\mathrm{BW}$, and $\mathrm{CL}$ with the formula:

$$
C F=10^{2} \times B W / C L^{3}
$$

Fish growth estimation commonly uses fish length frequency analysis. Furthermore, the strength of this analysis is that it is inexpensive, less timeconsuming, and does not require special expertise. This analysis is mostly performed by researchers on tropical fish resources.
Growth parameters $(\mathrm{K}, \mathrm{L} \infty)$ were analyzed using the electronic length-frequency analysis method (ELEFAN I), and scanning of $\mathrm{K}$-values was carried out with the FAO-ICLARM Stock Assessment Tool (FiSAT II) program (Gayanilo et al., 2005). Lobster growth curves were calculated, and analyzed using the equation of von Bertalanffy in Sparre, and Venema (1998). The equation is as follows:

$$
L t=L \infty\left\{1-\exp ^{(-k(t-t)))} \quad\right\} \text { where: } \mathrm{Lt}=\text { carapace }
$$
length at age $t ; L \infty=$ asymptotic carapace length when it reaches age $t$ years; $k=$ growth coefficient; $t$ $=$ lobster age; $\mathrm{t} 0=$ theoretical age when carapace length $=0$.

\subsubsection{Cohort (based on length distribution)}

The cohort identification method applies the assumption that the long frequency distribution of each cohort usually adheres to normal distribution (Jennings et al., 2001). Furthermore, the Bhattacharya method was used in separating the composite distribution from long frequencies (Spare and Vannema, 1998). In this research, the cohort was calculated based on the analysis of length groups using the normal separation procedure (NORMSEP), and progression analysis model.

\subsubsection{Recruitment}

The time-based recruitment patterns determination was analyzed using FiSAT II because the length- frequency distribution data had been set. This calculation was also involved in estimating all length-frequency distribution data into a one-year time scale based on the von Bertalanffy growth model (Pauly, 1982) using the NORMSEP. Furthermore, the estimation results were obtained by including the values of $\mathrm{CL}, \mathrm{K}$, and $\mathrm{t} 0$.

\subsubsection{Mortality}

Mortality and exploitation rate were calculated using FiSAT II program. Also mortality was measured from natural $(\mathrm{M})$, fishing $(\mathrm{F})$, and total $(\mathrm{Z})$ mortalities.

Empirical formula of Pauly (1984) which shows the effect of annual temperature was used in determining $M$ and exploitation rate. The equation is:

$\ln M=0,8 x \exp (-0,152-0,279 \ln L \infty+0,6534 \ln K+0,4634 \ln T)$ where: $\mathrm{L}=$ asymptotic length of fish $(\mathrm{mm}), \mathrm{K}=$ growth rate coefficient, and $\mathrm{T}=$ average surface temperature of waters $\left({ }^{\circ} \mathrm{C}\right)$. In this study, the surface temperature of the waters used is $30^{\circ} \mathrm{C}$, and was obtained from the results of direct measurements. In addition, natural mortality (M) is declared large if the value has reached 1.5 per year.

Total mortality was estimated by the equation of Beverton and Holt (1966) in Sparre et al. (1989). The equation is: $\quad Z=K(L \infty-L) /\left(L-L^{\prime}\right) \quad$ where: $\mathrm{Z}=$ total mortality rate (year), $\mathrm{K}=$ growth ratecoefficient, $\mathrm{L} \infty=$ 
scyphozoan asymptotic length $\mathrm{mm}) ; \mathrm{L}=$ average length of fully caught fish (mm), and L' = minimum length of fully caught fish (mm). According to Gulland in Sparre and Venema (1998), total mortality (Z) is the sum of natural mortality $(\mathrm{M})$ and fishing mortality $(\mathrm{F})$, following the formula: $Z=F+M$. Therefore, the fishing mortality value can be known through the equation: $F=Z-M$.

\subsubsection{Exploitation and fishing rate}

Exploitation rate (E) is obtained by comparing the value of $\mathrm{F}$ with $\mathrm{Z}$ or $\mathrm{E}=\mathrm{F} / \mathrm{Z}$ (Pauly, 1984). The levels of exploitation rate are: $\mathrm{E}>0.5=$ high exploitation (overfishing), $\mathrm{E}=0.5=$ optimal fishing, and $\mathrm{E}<0.5=$ low exploitation (under fishing) (Sparre and Venema, 1998). The authors divided the exploitation rate (E) into five categories of fishing status and the categories includes: (a) No Exploitation $(E=0.00)$, (b) Low Exploitation $(E=$ $>0.00-<0.50$ ), (c) Optimal Exploitation ( $E=0.50)$, (d) High Exploitation $(\mathrm{E}=>0.50-<1.00)$, and (e) Stop Exploitation $(\mathrm{E}=1.00)$.

Pauly (1984) explained that optimum fishing occurs when the $\mathrm{F}$ value is equal to the $\mathrm{M}$ value $\left(\mathrm{F}_{\mathrm{opt}}=\mathrm{M}\right)$.

To estimate its status, note the terms: (a) No Fishing $(\mathrm{FR}=0.0)$, (b) Less Fishing (FR $=>0-<1.0)$, (c) Optimum Fishing (FR = 1.0), (d) Excessive Fishing $(\mathrm{FR}=>1.0)$ and (e) Stop Fishing (FR = infinity).

Therefore, optimum fishing rate or $\mathrm{FR}$ opt is $\mathrm{F} / \mathrm{M}=1.0$.

\subsubsection{Carapace length at first catch}

Lobster carapace length at first catch (CLc) by fishing gear is also called $\mathrm{L}_{50 \%}$. That $50 \%$ value means the carapace length where $50 \%$ of the lobsters are stuck in the net and the other 50\% escapes the net (Sparre and Venema, 1998). The formula is as follows (Jones, 1976 in Sparre and Venema, 1998):

$$
S_{L} \text { est }=\frac{1}{1+\exp \left(S_{1}-S_{2}^{*} L\right)} \text { and } L_{50 \%}=\frac{S_{1}}{S_{2}}
$$

where: $S_{L}$ is the logistic curve (length-based tool selectivity), and $S_{1} \& S_{2}$ are constants in the lengthbased logistic curve equation $\left(S_{1}=a, S_{2}=b\right)$

\section{Results and Discussion}

\subsection{Growth pattern}

Analysis of the relationship between carapace length and body weight (LWR) of the two types of lobster obtained $a b$ value less than 3.0: 2.42 for $p$. penicillatus and 1.11 for $\mathrm{p}$. homarus (figure 2, table 1, figure 3).
$\mathrm{T}$ - test results for the value of $\mathrm{b}$, significantly showed different results $(\tilde{\mathrm{n}}<0.05)$ for the two types of lobster. This shows that the growth patterns of $P$. penicillatus, and $P$. homarus are the same, which is hypo-allometric. For the growth patterns of the two species of spiny lobster to be hypo-allometric $(b<3)$, it means the spiny lobster body is thin (Effendie, 2002).

Table 1. The result of LWR analysis spiny lobsters

\begin{tabular}{|c|c|c|}
\hline \multirow{2}{*}{$\frac{\text { Parameter }}{\mathrm{r}}$} & \multicolumn{2}{|c|}{ P. penicilatus $P$. homarus } \\
\hline & 0.932 & 0.631 \\
\hline R Square & 0.869 & 0.398 \\
\hline Adjusted R Square & 0.869 & 0.364 \\
\hline Standard Error & 0.143 & 0.250 \\
\hline Observations & 293 & 20 \\
\hline $\mathrm{a}$ & -4.689 & 0.702 \\
\hline $\mathrm{b}$ & 2.422 & 1.108 \\
\hline
\end{tabular}

Growth Pattern Hypo allometric Hypo allometric

\subsection{Condition factor}

CF value of $P$. penicillatus was between 0.034 , and 0.127 with an average value of 0.081 . The $\mathrm{CF}$ value of P. homarus was between 0.032 , and 0.110 (Figure 4). These very small $\mathrm{CF}$ values indicate that the population of both types of lobsters is dominated by the old ones.

\subsection{Growth coefficient $(K)$}

The growth coefficient $(K)$ value of $P$. penicillatus lobster was 0.75 year, and its $\mathrm{CL}_{\infty}$ value was 133.50 $\mathrm{mm}$. The value of $\mathrm{P}$. penicillatus $\mathrm{t}_{0}$ (theoretical age when $\mathrm{CL}=$ zero) based on Pauly's empirical formula (1984) was -0.4 years. For P. homarus lobster, the K value was $0.66 /$ year, $C L \infty$ value $=115.15 \mathrm{~mm}$, and $\mathrm{t}_{0}$ value based on Pauly's empirical formula (1984) was 0.2 years (Figure 5 ).

Maximum carapace length $\left(\mathrm{CL}_{\max }\right)$ of P.penicillatus observed was estimated to reach $127.14 \mathrm{~mm}$ with $95 \%$ confidence intervals of 112.96 to $139.38 \mathrm{~mm}$. Whereas observed $P$. homarus $\mathrm{CL}_{\max }$ was estimated to reach $109.67 \mathrm{~mm} 95 \%$ confidence interval of 71.90 to $125.27 \mathrm{~mm}$ (Figure 6).

\subsection{Growth curve}

Lobster growth is displayed in the form of curves using the Von Bertalanffy model. For P. penicillatus, the equation was $\mathrm{L}=133,50\left\{1-\exp ^{-0,79(t+0,4)}\right\}$. While the equation for $P$. homarus was $\mathrm{L}_{\mathrm{t}}=115.15$ \{1-exp $0.66(t+0.2)\}$. 
Table 2. Sampling results and average of CL

\begin{tabular}{ccc} 
& Sample (ind) & (mm) \\
\hline 11-21 May 2019 & 20 & 87.09 \\
22-31 May 2019 & 31 & 73.14 \\
01-10 June 2019 & 15 & 72.54 \\
11-20 June 2019 & 29 & 78.11 \\
21-30 June 2019 & 15 & 73.14 \\
01-02 July 2019 & 163 & 73.35 \\
06 July 2019 & 40 & 70.95 \\
\hline
\end{tabular}
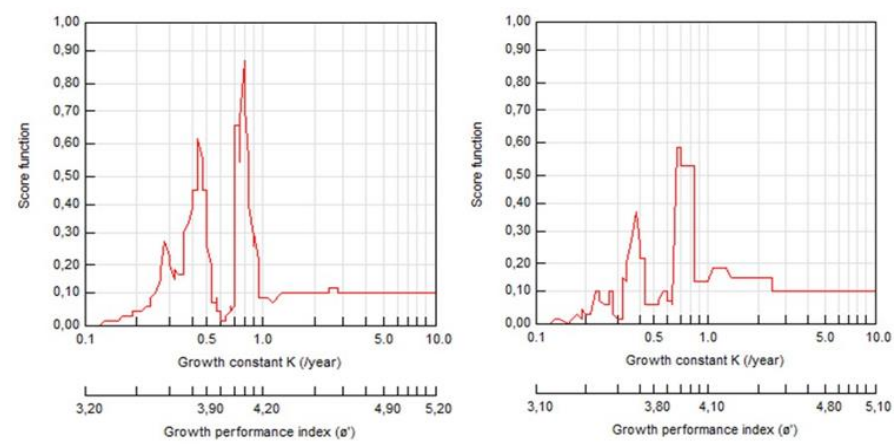

Figure 2. Growth coefficient value of Labangka's spiny lobsters
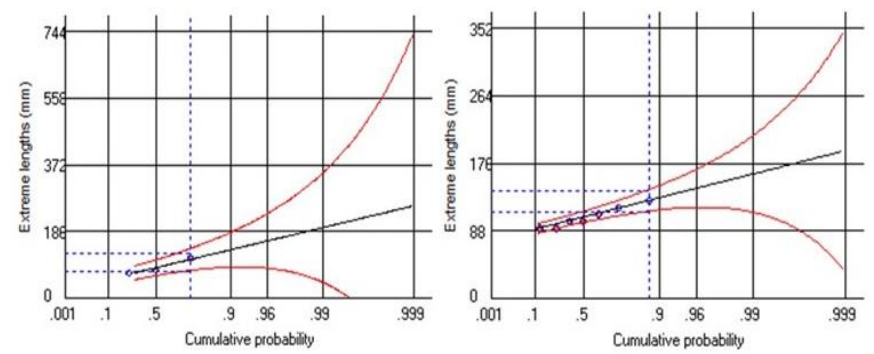

Figure 3. CL maximum of Labangka's spiny lobsters

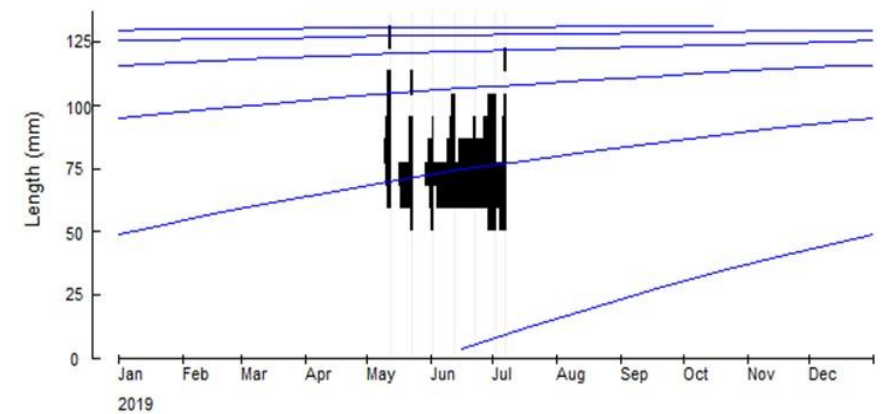

Figure 4. Growth curve of $P$. penicillatus

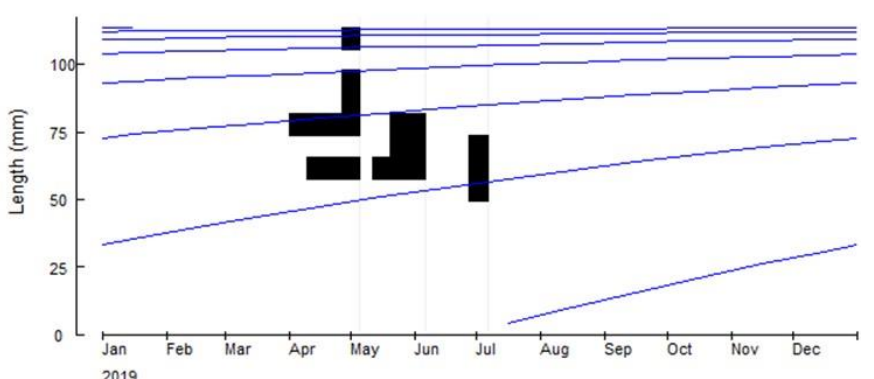

Figure 5. Growth curve of $P$. homarus
When P. penicillatus lobster is 1.0 years old, its theoretical carapace length could reach $89.33 \mathrm{~mm}$, while its asymptotic carapace length $\left(\mathrm{L}_{\infty}\right)$ of 133.50 $\mathrm{mm}$ is estimated to occur at the age of 9 years, and 5 months. The slowing rate of lobster carapace growth occurs when its age has reached 3 years, and 1 month (Figure 4). Meanwhile, when P. homarus is 1.0 years old, its theoretical carapace length could reach 62.99 $\mathrm{mm}$. While at the age of 15 years and 1 month, it is assumed that its asymptotic carapace length $\left(\mathrm{L}_{\infty}\right)$ could reach $115.15 \mathrm{~mm}$. Furthermore, at the age of 3 years 5 months, a slowing down of carapace growth rate occurs (Figure 5).

\subsection{Population parameters}

\subsubsection{Cohort}

Length-based cohort was analyzed using the model progression analysis NORMSEP. The aim was to obtain a length-based cohort that is similar to the age cohort from each sampling.

\subsubsection{Panulirus penicillatus}

Each sampling found one type of length or age group. From the $2^{\text {nd }}$ to $6^{\text {th }}$ sampling activities, the information obtained was that lobsters that were caught appeared to be similar. Furthermore, it was alleged that they were still in the same age group or cohort (Figure 6). Whereas in the $1^{\text {st }}$ sampling, one age group was suspected to be older compared to the later cohort samplings.

\subsubsection{Panulirus homarus}

Based on the sampling results from May to July, the $P$. homarus captured appeared to be uniform in size to the extent that they were believed to be in one cohort. In May sampling, it was discovered that one age group was suspected to be older compared to other subsequent cohort sampling (Figure 7). From sampling activities on May 2019, there were 10 individualal lobsters with an average carapace length of $78.47 \mathrm{~mm}$. From sampling in June 2019, we obtained 7 individualals with an average carapace length of $63.53 \mathrm{~mm}$. Sampling in July 2019, there were 3 individualals with an average carapace length of $61.67 \mathrm{~mm}$.

\subsection{Recruitment}

The population was strongly influenced by the addition of new individualals, especially those sourced each year. In Labangka waters, the recruitment of $P$. penicillatus and $P$. homarus took place every month throughout the year (Figure 8). 


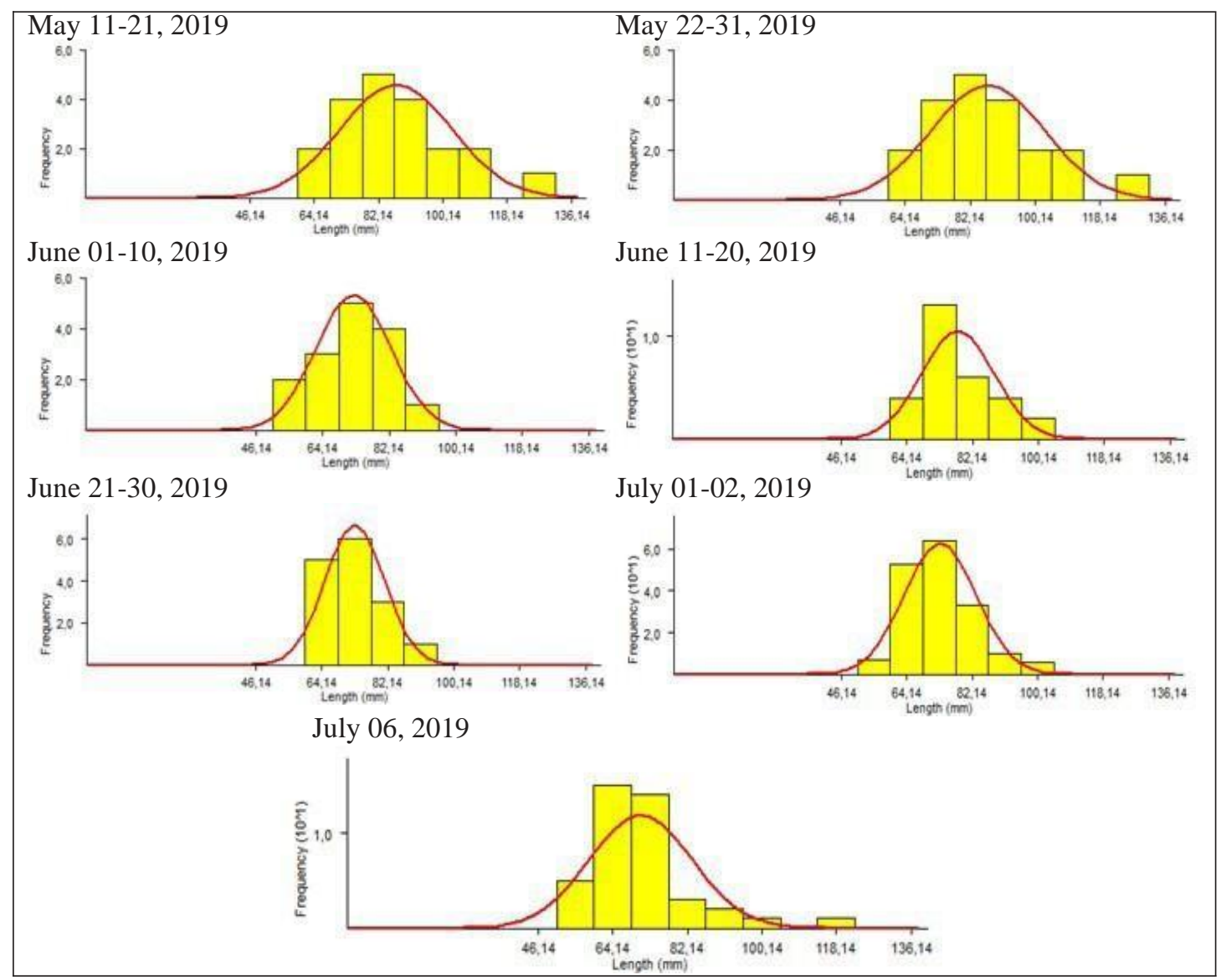

Figure 6. Monthly analysis of $P$. penicillatus cohort

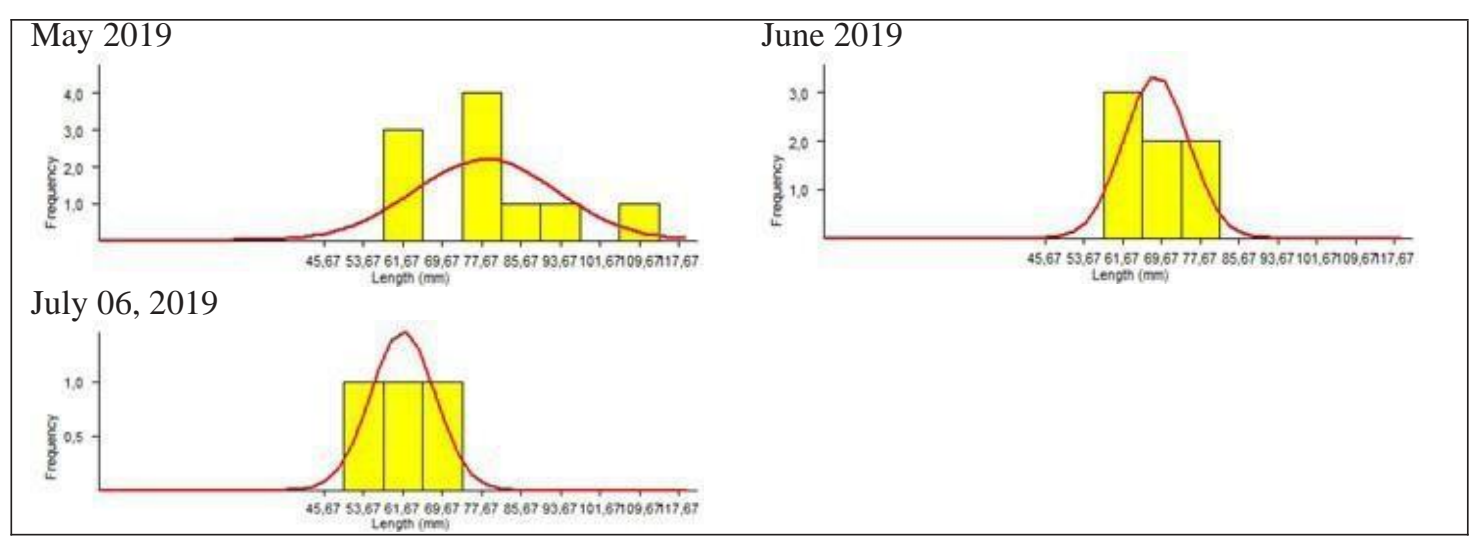

Figure 7. Monthly analysis of $P$. homarus cohort
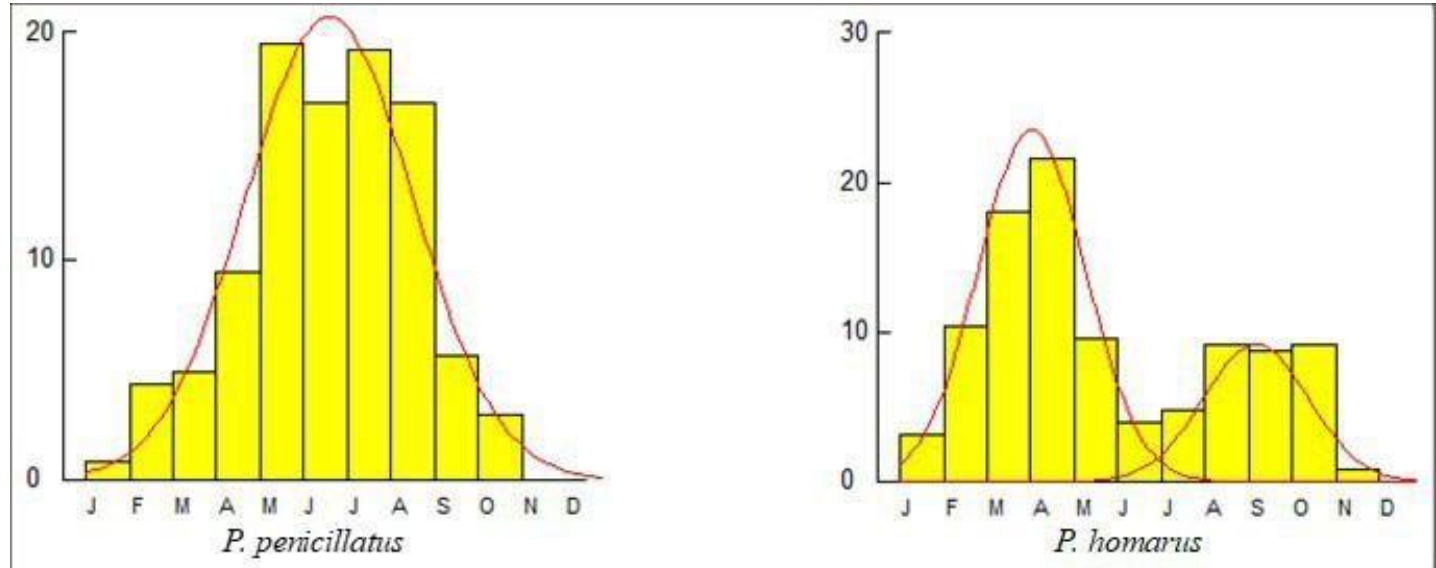

Figure 8. Annual recruitment pattern of spiny lobsters from Labangka 
Peak recruitment of $P$. penicillatus occurred in May at $19.55 \%$. Note, one peak spawning season occurs every year. Therefore, this assumption is based on the peak recruitment pattern that occurred, meaning in that month, the fish population was relatively abundant, and exploited.

Peak recruitment of $P$. homarus occurred in April by $21.76 \%$. In the following months, a decline in recruitment occurred, and persisted until July. However, in August, it increased once more by $9.11 \%$.

\subsection{Mortality}

Lobster fish resource mortality indicates natural, and human activities that do not support the existence of fish resources. The total mortality $(\mathrm{Z})$ of $P$. penicillatus was $4.25 /$ year, which was the sum of its $M$ value at 1.04 per year, using an average annual surface water temperature of $30^{\circ} \mathrm{C}$, with an $\mathrm{F}$ value of 3.21 per year. Whereas P. homarus had a $\mathrm{Z}$ value of 1.29 per year. This was the sum of its $M$ value, at an average annual surface water temperature of $30^{\circ} \mathrm{C}$. Furthermore, it amounted to 0.97 per year, along with an $\mathrm{F}$ value of 0.33 per year (Figure 12).

\subsection{Carapace length at first capture}

Carapace length at first capture (CLc) was 67.5 $\mathrm{mm}$ and $65.7 \mathrm{~mm}$ for $P$. penicillatus, and $P$. homarus respectively (Figure 10). Referring to the research data, it was known that $P$. penicillatus body weight (BW) of 204.00 g/individual occurred at $\mathrm{CLc}=62.63$ $\mathrm{cm} /$ individual. Whereas $P$. homarus with CLc $=63.57$ $\mathrm{mm} /$ individual, with a body weight of $256 \mathrm{~g} /$ individual.

The enactment of regulations limiting the size of lobster for harvesting in Indonesia, has been carried out since January 2015. Hopefully, this long period has been able to leverage, lift, and restore the condition of individualals and populations of lobster resources in Indonesian waters.

Lobster growth parameters, and population are part of biological dimensions that are vital for responsible, and sustainable fishery management. The attributes of sustainable potential, growth patterns, condition factors, and growth coefficients are the main standards in assessing the suitability status, and existence of lobsters individualally.

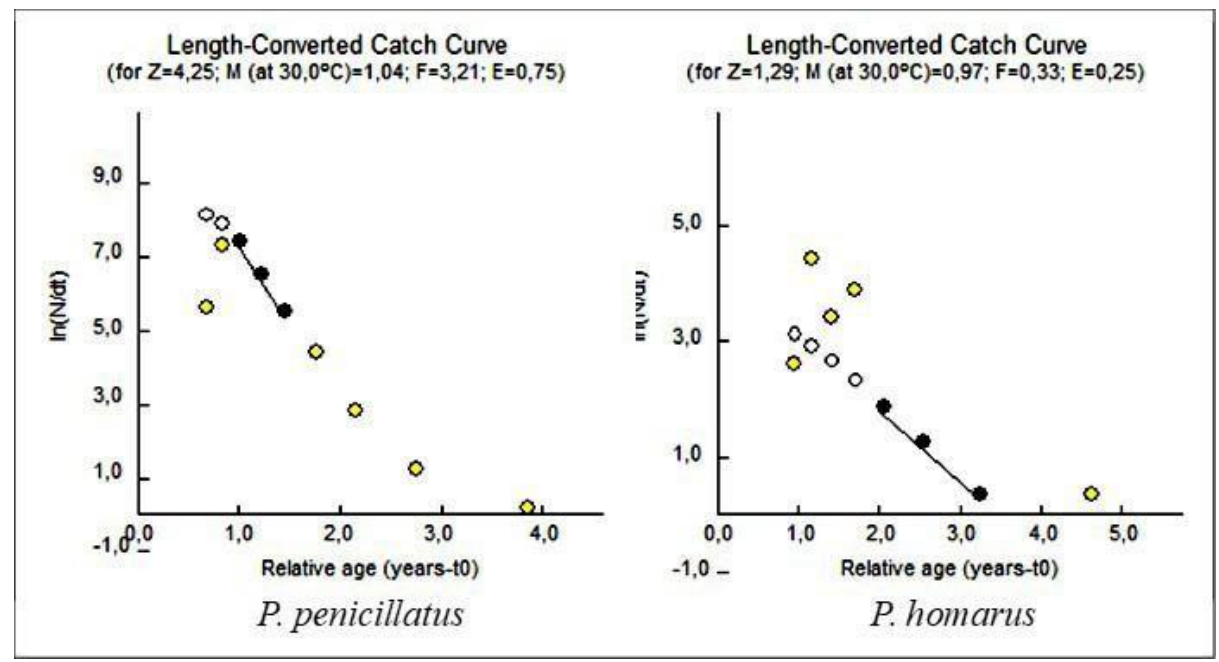

Figure 9. Linearized lobster catch curve in Labangka that linearized based on CL composition
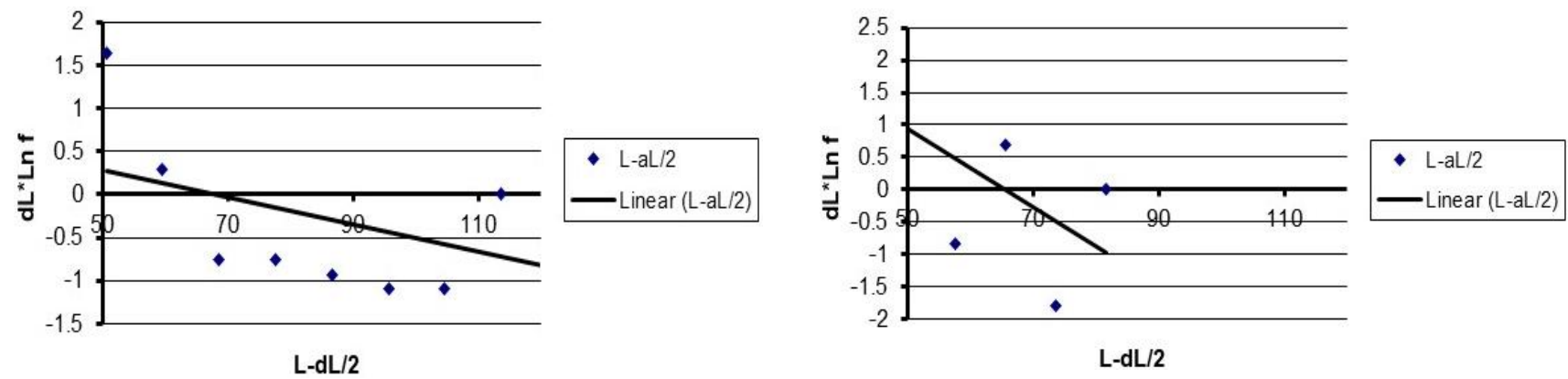

Figure 10. The value curve of CLc 
JIPK. Volume 12 No 2. November 2020 / Growth and Population Parameters of Panuliruspenicillatus and Panulirus homarus....

The desired result was the individualal security and population of lobster resources becoming the core components for the preparation and implementation of responsible, and sustainable lobster fishery management strategies.

Growth patterns $(<3.0)$ and condition factors $(<1.0)$ of Labangka lobsters indicates a thin-bodied and slightly flat lobster. From the age of 3 years and 1 month onwards, its carapace growth rate has slowed down. Furthermore, this statement is similar to Effendie's (2002) who argued that this condition indicated that the lobster is old, and its body lacks enough flesh (rather flat). Based on that assumption, it is suspected that lobsters in Labangka waters are old, and their body weight increases very slowly. This is due to low utilization rate, as reported by Munandar et al. (2019).

Growth of P. penicillatus $\left(\mathrm{K}=0.75 /\right.$ year; $\mathrm{CL}_{\infty}=$ $133.50 \mathrm{~mm})$, and P. homarus $\left(\mathrm{K}=0.66 /\right.$ year; $\mathrm{CL}_{\infty}=$ $115.15 \mathrm{~mm}$ ) from Labangka are similar to lobsters in several other Indonesian waters. In areas along the southern coast of Java, P. penicillatus growth had a value of $\mathrm{K}=0.19-0.85 /$ year, and $\mathrm{CL}_{\infty}=125.00-145.75 \mathrm{~mm}$ (Mahasin, 2003; Zaenuddin and Putri, 2017; Larasati et al., 2018). Whereas $P$. homarus species in Indonesian waters had a range of values of $\mathrm{K}=0.26-0.40$ /year and $\mathrm{CL}_{\infty}=103.50-119.15 \mathrm{~mm}$ (Bakhtiar et al., 2013; Kembaren and Nurdin, 2015; Zairion et al., 2017).

The growth rate of lobsters from Labangka waters is considered to be slow (0.19-0.85/year). Furthermore, Sparre and Venema(1998) argued that growth coefficient (K) less than 1.0 per year ( $\mathrm{K}<1.0 /$ year) is considered to be slow. In other words, both types of spiny lobsters require a long time to grow and reach adult size, for it to be worth catching and selling, as well as to be parentsized. A striking difference in the growth coefficient of $P$. homarus may be due to differences in the number of lobster samples. The high K value of Labangka lobsters indicates that they are to be used sustainably with a maximum of $80 \%$ of MSY (fully exploited). Therefore, the availability of lobster resources in lobster fishery management can remain in a sustainable status.

The asymptotic carapace length of lobsters from Labangka waters predominantly exceeds the asymptotic carapace length of similar lobsters in Indian Ocean waters at various regions in Indonesia. This illustrates that the sand lobsters in Labangka waters live longer with a growth rate that tends to be slower when compared to similar lobsters in Indian Ocean waters in Indonesian territory.

In Labangka waters, lobsters are suspected to undergo recruitment throughout the year. The peak recruitment of $P$. penicillatus occurs once a year and that of $P$. homarus occurs twice a year. This is based on the pattern of peak recruitment that occurred which means in that month, the fish population was relatively abundant and exploited. This statement is in line with Effendie (2002) who stated that recruitment is the addition of new individualals into the fishery stock. The addition of new individualals in a body of water of each size class is closely related to the condition of environmental factors (Dodds, 2002).

Related to environmental factors, the estimated natural mortality $(\mathrm{M})$ of lobster in Labangka waters was analyzed at an average annual water temperature of $30^{\circ} \mathrm{C}$. The analysis resulted in the value of $\mathrm{M}$ for $P$. penicillatus $=1.04 /$ year and $P$. homarus $=0.97 /$ year, which indicates low natural mortality for Labangka lobsters. This statement is in line with Pauly (1984) who stated that $\mathrm{M}$ is high if the value is higher than $1.5 /$ year. If natural mortality is analyzed with normal water temperature $\left(28.5^{\circ} \mathrm{C}\right)$, the natural mortality would be lower. Therefore, this $\mathrm{M}$ status shows that coral reef ecosystems and seagrass beds at the bottom of the waters are still in good condition.

Meanwhile, the lobster mortality rate due tofishing (F) indicates that the level of P. penicillatus exploitation $(\mathrm{F}=3.21$ /year) was in the relatively intensive category while the mortality rate of $P$. homarus $(\mathrm{F}=0.97 /$ year $)$ was relatively extensive. Furthermore, $M$ values ranging from 0.97-1.04 per year indicate low natural mortality. This is in line with Pauly (1984) who stated that natural mortality is low if the $\mathrm{M}$ value is less than 1.5 / year. Based on $\mathrm{F}$ and $\mathrm{M}$ values, it is assumed that the $P$. penicillatus and $P$. homarus resource stocks are still safe in the waters. Munandar et al. (2019) stated that the level of utilization of $P$. penicillatus is in the "lightly exploited" status ( $<50 \%$ MSY).

Exploitation rate value (E) of P. Penicillatus (0.75/ year) and $P$. homarus $(0.25 /$ year) respectively are already in the high and low exploitation status. Meanwhile, the value of fishing rate (FR) of P. Penicillatus, and $P$. homarus is 3.09 and 3.91. This values indicate excessive fishing. These are the same status as P. penicillatus' that lives in the southern coastal waters of Yogyakarta where its exploitation status is high (overfishing) $(\mathrm{E}=0.56$ $0.68)$, and its fishing rate status is excessive ( $\mathrm{FR}=1.28$ 2.16) (Larasati et al., 2018). The status of $P$. homarus in West Aceh waters has values of $\mathrm{E}=0.53$ and $\mathrm{FR}=$ 1.15 (Kembaren and Nurdin, 2015). This conditions indicates the high intensity of the two types of spiny lobster capture by fishermen. 
Table 3. CLc and $0.5 \mathrm{CL}_{\infty}$ of spiny lobsters

\begin{tabular}{|c|c|c|c|c|}
\hline Species/Location & Source & $\begin{array}{l}\text { CLc } \\
(\mathrm{mm})\end{array}$ & $\begin{array}{l}0.5 C L \\
\infty(\mathrm{mm})\end{array}$ & $\begin{array}{l}\text { CLe/ } \\
0.5 C L \\
\infty\end{array}$ \\
\hline \multicolumn{5}{|l|}{ P. penicillatus } \\
\hline Labangka waters & This research (2019) & 67.50 & 66.80 & 1.01 \\
\hline Wonogiri waters & $\begin{array}{l}\text { Zaenuddin \& Putri } \\
\text { (2017) }\end{array}$ & 56.00 & 67,00 & 0.84 \\
\hline \multicolumn{5}{|l|}{ P. homarus } \\
\hline Labangka waters & This research (2019) & 65.70 & 57.88 & 1.14 \\
\hline Aceh Barat waters & $\begin{array}{l}\text { Kembaren \& Nurdin } \\
\text { (2017) }\end{array}$ & 65,80 & 59.75 & 1.10 \\
\hline
\end{tabular}

The carapace length at first capture (CLc) of $P$. penicillatus from Labangka was $67.50 \mathrm{~mm}$ longer than $0.5 \mathrm{CL}_{\infty}(66.78 \mathrm{~mm})$. While the $P$. penicillatus research in Wonogiri waters in 2014 showed that the CLc $(56.00 \mathrm{~mm})$ was shorter than $0.5 \mathrm{CL}_{\infty}(67.00 \mathrm{~mm})$ (Zaenuddin and Putri, 2017). Furthermore, the carapace length at first capture of $P$. homarus was $65.70 \mathrm{~mm}$, which is longer than the length of $0.5 \mathrm{CL}_{\infty}(57.88 \mathrm{~mm})$. In the waters of West Aceh, P. homarus has aCLc of $65.80 \mathrm{~mm}$, longer than the length of $0.5 \mathrm{CL}_{\infty}(59.75$ mm) (Kembaren and Nurdin, 2015) (Table. 3). Based on Table 3, if the value of the carapace length ratio becomes higher, then it is suspected that: (a) the stock of lobster parent candidates is increasing, (b) the chance of lobster reproducing is increasing, and (c) members of the young lobster population is increasing.

\section{Conclusion}

Numerous studies about lobster biology have been carried out in both national and international scientific journals and forums. If the results of the study are paired with the regulations of MAF Ministry, then the purpose of regulations has not been reached, especially on the management of $P$. penicillatus and $P$. homarus. Therefore, the Government of Indonesia needs to conduct holistic review to prepare the strategic plan of sustainable lobster fishery to become effective and efficient.

\section{Acknowledgment}

On behalf of the University of 45 Mataram, we acknowledge the Ministry of Research, Technology and Higher Education of the Republic of Indonesia (DRPM DJPRP Kemristekdikti RI) that funded this research (Contract number: 0900/L8/KM/2019 in $27^{\text {th }}$ of March 2019).

\section{Author's Contributions}

The authors have contributed very well, from designing research to checking the draft final of the manuscript before it is sent to journal managers. Evron
Asrial designs and carries out surveys, monitors data processing and analysis activities, also writes research reports and scientific publication manuscripts. Hamid and Naning Dwi Sulistyaningsih compiled, tabulated, and separated the data, especially the lobster sampling results. Erwin Rosadi and Agustin Dwi Sumiwi carried out quantitative data processing, and write down the resume. Najiah Khalisah and Ruly Isfatul Khasanah analyzed the results of data processing. Meanwhile, Muhammad Ichsan revised and perfected sentences and vocabulary in the publication manuscript.

\section{Conflict of Interest}

The authors declare that they have no competing interests.

\section{Funding Information}

This research was funded by the Ministry of Research, Technology and Higher Education with grant number: 0900/L8/KM/2019 in $27^{\text {th }}$ of March 2019.

\section{References}

Bakhtiar, N. M., Solichin, A., \& Saputra, S. W. (2013). Pertumbuhan dan laju mortalitas lobster batu hijau (Panulirus homarus) di perairan Cilacap, Jawa Tengah. Journal of Management Aquatic Resources, 2(4):1-10.

Dodds, W. K. (2002). Freshwater ecology. Concepts and environmental applications. San Diego: Academy Press. An Elsevier Science Imprint.

Effendie, M. I. (2002). Fisheries biology. (Indonesian). Yogyakarta: The Foundation of Pustaka

Nusantara,

Gayanilo, F. C. Jr., Sparre, P., \& Pauly D. (2005). The FAO ICLARM stock assessment tools II (FiSAT II). Revised Version. User's Guide. FAO Comput. Inf. Ser. Fish. No. 8:168p.

Jennings, S., Kaiser, M.J., \& John D. Reynolds.(2001). Marine fisheries ecology. Oxford: Blackwepp Publishing.

Junaidi, M., Cokrowati, N., \& Abidin, Z. (2010). Reproductive aspect of lobster (Panulirus sp.) in Eks Bay waters, Lombok Island. Indonesian Journal of Marine Science and Technology, 3(1): 29-35.

Kembaren, D. D., \& Nurdin, E. (2015). Length distribution and population parameters of scalloped spiny lobster (Panulirus homarus) in west Aceh waters. Bawal Widya Riset Perikanan Tangkap, 7(3): 121-128.

Kembaren, D. D., Lestari, P. \& Ramadhani, R. (2015). Biological parameters of scalloped spiny lobster (Panulirus homarus) in Tabanan waters, Bali. Bawal Widya Riset Perikanan Tangkap, 7(1): 35- 
JIPK. Volume 12 No 2. November 2020 / Growth and Population Parameters of Panulirus penicillatus and Panulirus homarus....

42.

Larasati, R. F., Suadi, \& Setyobudi, E. (2018). Population dynamics of double-spined rock lobster (Panulirus penicillatus Olivier, 1791) in Southern Coast of Yogyakarta. Biodiversitas Journal of Biological Diversity, 19(1): 337-342.

Mahasin, M. Z. (2003). Kajian stok dan bioekonomi lobster (Panulirus spp.) untuk menunjang pemanfaatan berkelanjutan di Propinsi Daerah Istimewa Yogyakarta. Tesis. Semarang: Program Pasca Sarjana. Universitas Diponegoro.

Munandar, A., Asrial, E., Hamid, \& Rosadi, E. (2019). Fisheries resource status of spiny lobster Panulirus penicillatus in Labangka Waters, South Sumbawa, Indonesia. International Journal of Recent Scientific Research, 10(08B): 34128-34132.

Pauly, D. (1982). A method to estimate the stockrecruitment relationship of shrimps. Transactions of the American Fisheries Societ, 111: 13-20.

Pauly, D. (1984). Fish population dynamics in tropical waters: A manual for use with programmable calculators. Manila:The International Center for Living Aquatic Resources Management.

Pratiwi, R. (2018). Keanekaragaman dan Potensi Lobster (Malacostraca: Palinuridae) di Pantai
Pameungpeuk, Garut Selatan, Jawa Barat. Majalah Ilmiah Biologi Biosfera, 35(1): 10 - 22.

Salim, A., Asrial, E., Liliyanti, M. A., Hamid, \& Rosadi, E. (2019). Reproductive biological aspect of Panulirus penicillatus in Sumbawa Island Waters, Indonesia. International Journal of Recent Scientific Research, 10(08F): 34372-34377.

Sparre, P., \& Venema, S. C. (1998). Introduction to tropical fish stock assessment. Part 1. Manual. Rome: FAO Fish. Tech. Pap. (306/1) Rev. 1: 376 pp.

Sparre, P., Ursin, S., \& Venema, C. (1989). Introduction to tropical Fish Stock Assessment, Part I Manual. Rome.

Zaenuddin, M., \& Putri, D. A. D. (2017). Size composition of lobster (Panulirus penicillatus) in Wonogiri waters, Central Java. Indonesian Journal of Fisheries Science and Technology, 12(2): 109115.

Zairion, Islamiati, N., Wardiatno, Y., Mashar, R. A., Wahyudin, A., \& Hakim, A. A. (2017). Population dynamics of scalloped spiny lobster (Panulirus homarus Linnaeus, 1758) in Palabuhan Ratu waters, West Java. Jurnal Penelitian Perikanan Indonesia, 23(3): 215-226. 